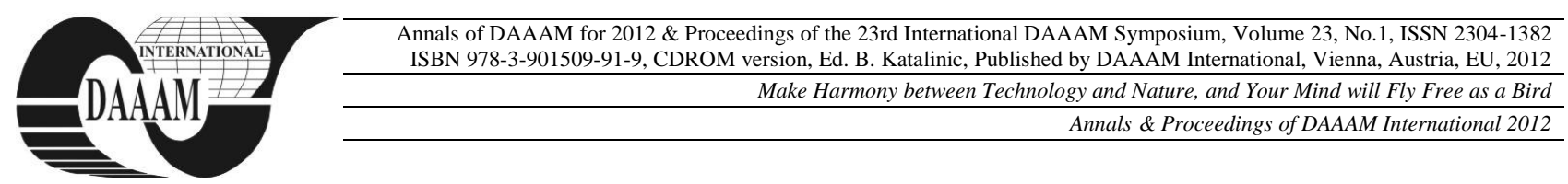

\title{
MONITORING OF THERMAL DEGRADATION OF FIREPROOF COATING
}

\author{
CHREBET, T[omas]; MARTINKA, J[ozef]; HRUSOVSKY, I[van] \& BALOG, K[arol]
}

\begin{abstract}
Under the fire conditions, the resistance of cable distribution is required for a fixed period, depending on the intended use of the cable. To increase the fire resistance of cables a fireproof coating may be applied. Article deal with the behavior of the fireproof coating during elevated temperature. Concretely, the aim is monitored a coating weight change under the conditions of dynamically increasing temperature and with or without using air-flow. It is also monitored the change in weight, depending on the isothermal temperatures in dynamic air atmosphere.
\end{abstract}

Keywords: fireproof coating, weight lost, dynamic temperature, isothermic temperature

\section{INTRODUCTION}

Fire protection coating systems can be divided into following categories [1]:

- barriering - which prevent causing as a barrier between direct contact of flame and atmospheric oxygen with the surface of the protected material, while also limiting the penetration of thermal decomposition products into the environment (particularly suitable for protecting wires, plastic and wood constructions),

- intumescent (foaming) - at temperatures characteristic for the fire the coating made on the protecting surface foam layer of the carbon residue, which acts as insulation (particularly suitable for the protection of cables, steel and wood constructions),

- sublimating - their protective effect is based on a strongly endothermic reaction at sublimation, which occurs at temperatures of fire.

Dexaflamm-R, is fireproof coating used to protect cables and fire plugs and for sealing of construction joints. It is used to protect of cables external insulation based on polyvinyl chloride (PVC), polypropylene (PP) and linear polyethylene (HDPE). It is white and gray cement with visible alumino-silicate fiber. The density of Dexaflamm- $\mathrm{R}$ is 1,4 g.cm ${ }^{-3}$ with a very high viscosity. After drying at ambient temperature and humidity, coating is resistant to water and normal weather conditions $[2,3]$.

The coating is not suitable for use in highly alkaline conditions and environment of organic vapors. At temperatures below zero and strong dynamic straining may occur a loss of adhesion to the substrate or cracking [2].

To protect of the cables is coating used in the layer of 3 to $6 \mathrm{~mm}$ thickness. Coating prevents the flame spread over the surface of the protected cable, limiting the amount of thermal decomposition products released into the atmosphere from the cable insulation under thermal loads and allow to achieve the functionality of the cable in define time under the conditions of the fire. According to EN 13501-1 + A1: 2010 [4] , is classified in category of reaction to fire $\mathrm{B}-\mathrm{s} 1$, d0. Life of the coating is at least 30 years [2].

The protective effect of fire coating is determined separately for each application by standardized test methods. For the coatings used to protect cables are evaluated performed requirements for resistance to flame propagation, low smoke density under conditions of fire, circuit integrity in case of fire and/or functional immunity in the fire. So fire coatings are not tested separately, but in the combined with the protected elements. The chosen methodology allows to assess of interaction effects of the protected material (surface) coated by fireproof coating on the protective effect under fire conditions (tests).

Despite these facts, the influence of external conditions (temperature) on the protective effect of the fire protection coating can be assessed by determining changes of coating properties due to exposure to increased and high temperatures. Good indicators of changes in the properties of fire protection coatings due to exposure to increased and high temperatures are mass loss, mass loss rate and chemical composition of the released gaseous products of thermal decomposition.

\section{PRINCIPE OF EXPERIMENT}

Experiment was realized in a modified electrically heated hot air furnace called Setchkin furnace (according to ISO STN 871 standard) Connection of Setchkin furnace with precise weight with accuracy to $0,001 \mathrm{~g}$ allow measuring the mass loss during thermal straining. The measurements can be realized under dynamic conditions (constant heating rate) and isothermal conditions (constant temperature). This modified electrically heated hot air furnace allow to use samples at weights higher than $5 \mathrm{~g}$, which is more than in normal thermal gravimetry [5].

For experiment were selected two temperature programs:

- Dynamic heating by rate of $5{ }^{\circ} \mathrm{C} \cdot \mathrm{min}^{-1}$, in the temperature range from $25^{\circ} \mathrm{C}$ to $650{ }^{\circ} \mathrm{C}$, air-flow velocity was set to $31 . \mathrm{min}^{-1}$, and experiment was realized also withou airflow. Dynamic heating was chosen to map the behavior of the coating in a wide temperature range. 
- Isothermal measurements were realized at temperatures: $600{ }^{\circ} \mathrm{C}, 500{ }^{\circ} \mathrm{C}, 400{ }^{\circ} \mathrm{C}, 300{ }^{\circ} \mathrm{C}, 200$ ${ }^{\circ} \mathrm{C}, 100{ }^{\circ} \mathrm{C}$, air-flow velocity was set according to the ISO STN 871 standard to $25 \mathrm{~mm} . \mathrm{s}^{-1}$ [6]. Isothermal measurements were chosen for assess the behavior of the coating at selected temperatures.

\section{RESULTS OF THE DYNAMIC HEATING}

The results of experimental tests of thermal decomposition of the fireproof coating Dexaflamm-R under dynamic conditions are given in Tab. 1. Graphical presentation of results with distribution to individual stages are on Fig.1 and Fig. 2.

\begin{tabular}{|c|c|c|c|c|c|c|}
\hline $\begin{array}{c}\text { Experimental } \\
\text { conditions } \\
\text { Sampe weight }[\mathrm{g}]\end{array}$ & $\begin{array}{c}\text { Decomposition } \\
\text { stages }\end{array}$ & $\begin{array}{l}\text { Temperature range } \\
\qquad\left[{ }^{\circ} \mathbf{C}\right]\end{array}$ & $\begin{array}{c}\text { Mass loss } \\
{[\%]}\end{array}$ & $\begin{array}{c}\text { Temperature at } \\
\text { maximal mass } \\
\text { loss rate } \\
{\left[{ }^{\circ} \mathrm{C}\right]}\end{array}$ & $\begin{array}{l}\text { Maximal mass } \\
\text { loss rate }\left[{\mathrm{g} . \mathrm{s}^{-1}}^{-1}\right.\end{array}$ & $\begin{array}{l}\text { Resistant } \\
\text { residue [\%] }\end{array}$ \\
\hline \multirow{4}{*}{$\begin{array}{c}\text { Heating rate } \\
5^{\circ} \mathrm{C} \cdot \mathrm{min}^{-1}, \text { air-flow } \\
\text { rate } 3 \text { l.min } \\
5,060 \mathrm{~g}\end{array}$} & First stage & $25,5-275,5$ & 20,02 & 223,5 & 0,0008 & 79,98 \\
\hline & Second stage & $275,5-327,1$ & 10,03 & 302,3 & 0,0030 & 69,95 \\
\hline & Third stage & $327,1-411,1$ & 11,83 & 372,7 & 0,0010 & 58,12 \\
\hline & Fourth stage & $411,1-643$ & 8,131 & 483,1 & 0,0005 & 49,99 \\
\hline \multirow{4}{*}{$\begin{array}{c}\text { Heating rate } \\
5^{\circ} \mathrm{C} \cdot \text { min }^{-1} \text {, without } \\
\text { air-flow } \\
5,467 \mathrm{~g}\end{array}$} & First stage & $25-293,5$ & 20,31 & 240 & 0,0011 & 79,69 \\
\hline & Second stage & $293,5-344,8$ & 9,83 & 326,5 & 0,0043 & 69,86 \\
\hline & Third stage & $344,8-416,8$ & 11,74 & 387,5 & 0,0012 & 58,12 \\
\hline & Fourth stage & $416,8-652$ & 8,9 & 520 & 0,0004 & 49,22 \\
\hline
\end{tabular}

Tab. 1. Results of the thermal decomposition under dymanic heating by rate of $5^{\circ} \mathrm{C} \cdot \mathrm{min}^{-1}$

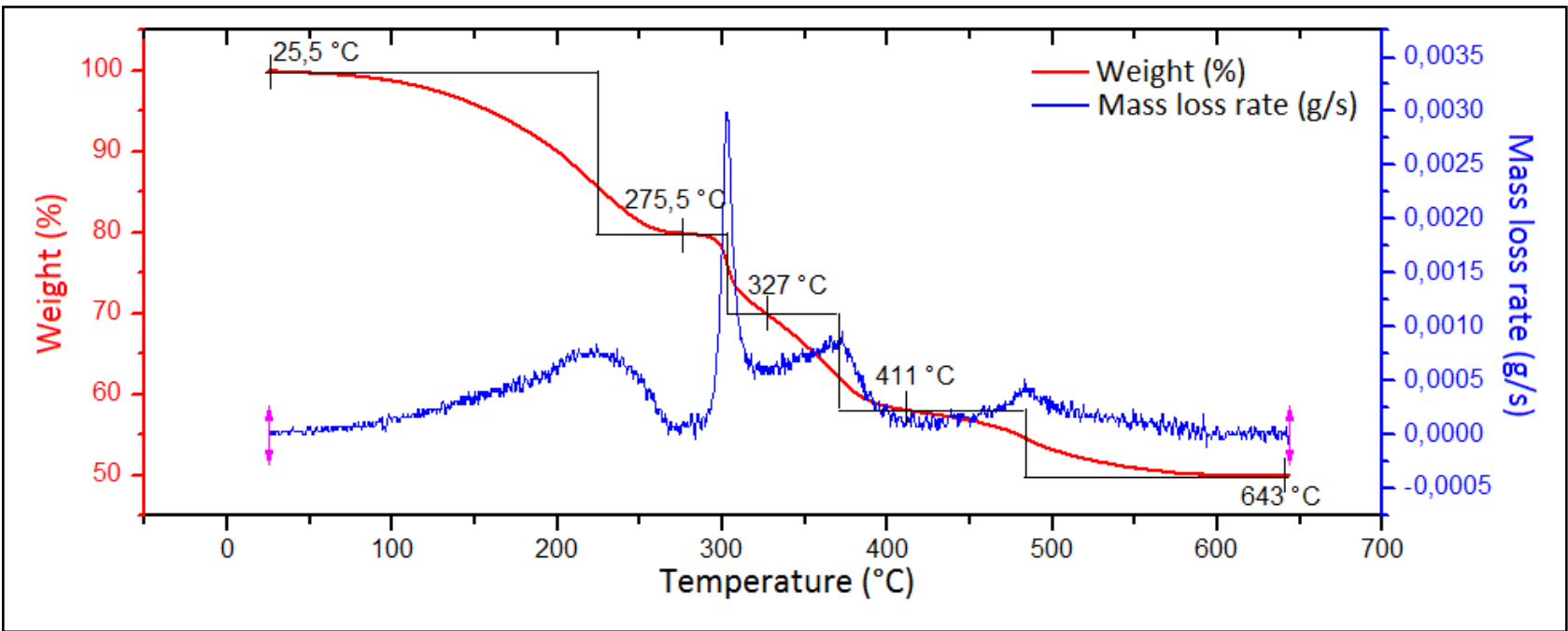

Fig. 1.Temperature dependance of weight and mass loss rate, under conditions of $5{ }^{\circ} \mathrm{C} \cdot \mathrm{min}^{-1}$ heating rate and air-flow rate $31 . \mathrm{min}^{-1}$

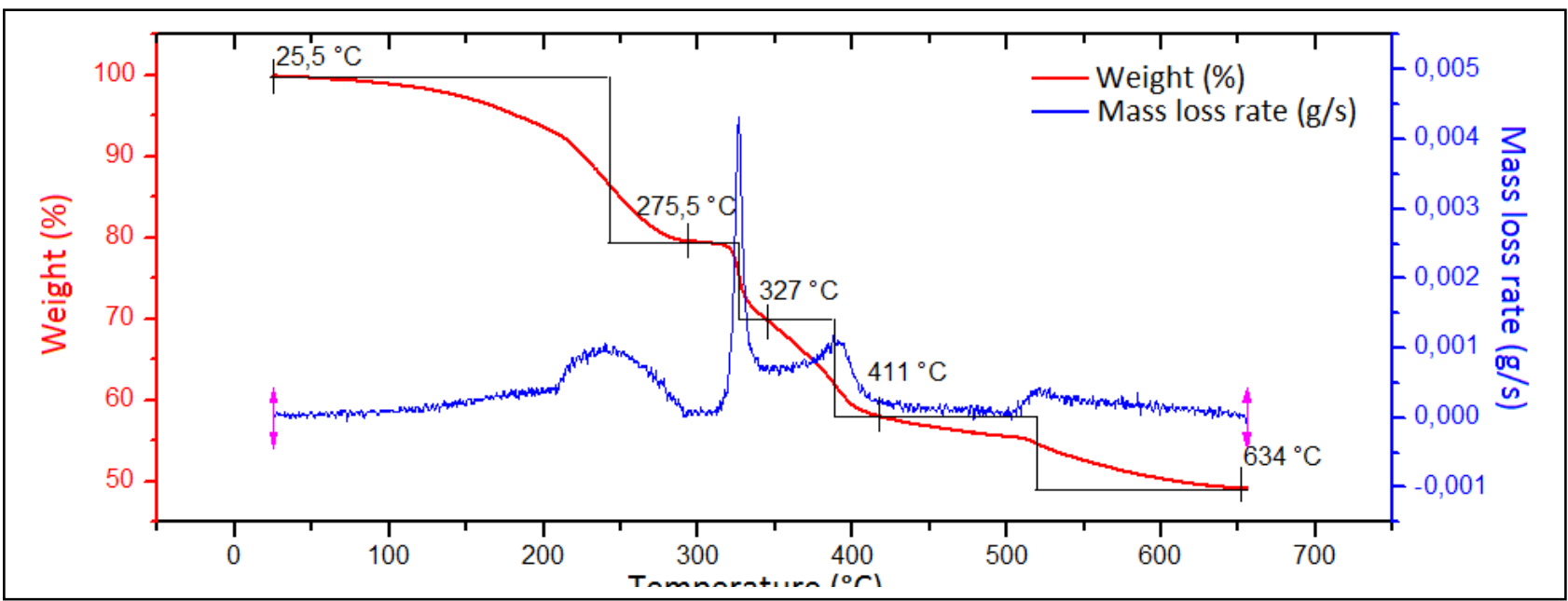

Fig. 2.Temperature dependance of weight and mass loss rate, under conditions of $5^{\circ} \mathrm{C} \cdot \mathrm{min}^{-1}$ heating rate and without air-flow 
In the table are information about numbers of decomposition stages, temperature range of stages, mass loss, temperature at maximal mass loss rate, maximal mass loss rate and resistant residue.

Based on a comparison of the results can be stated that using the air flow and no air flow, the samples behave nearly as well. In the first stage of decomposition weight loss was about $20 \%$, this weight loss was probably associated with the release of volatile components and moisture. The main decomposition with the highest mass loss rate took place in the second stage. For the possibility of comparing the mass loss rate this values were calculated to percent per second. In terms of air flow the maximum mass loss rate $0.059 \% . \mathrm{s}^{-1}$ was achieve at $302{ }^{\circ} \mathrm{C}$. This value was lower than without used air flow, when the maximum mass loss rate was $0.079 \% . \mathrm{s}^{-1}$ at $327^{\circ} \mathrm{C}$. Weight loss in the second stage of decomposition was approximately $10 \%$. The third stage of decomposition was associated with weight loss by $12 \%$, the maximum mass loss rate did not reach high values. In the final fourth stage of decomposition weight loss was about $8,1 \%$ respectively $8,9 \%$. The maximum mass loss rate in the final stage of decomposition reached the lowest values. Resistant residue after thermal decomposition at about $650{ }^{\circ} \mathrm{C}$ was below $50 \%$ for both samples.

\section{RESULTS OF THE ISOTHERMAL CONDITIONS}

Before the test begin, the furnace was heated to the desired temperature and allowed to stabilize for 60 minutes. Air-flow velocity was set up according to (1) at $25 \mathrm{~mm} . \mathrm{s}^{-1}$ [6]. The measurement started at temperature of $600{ }^{\circ} \mathrm{C}$ and at each subsequent measurement was temperature decreased by $100^{\circ} \mathrm{C}$. Samples were inserted into the furnace within 20 seconds. During this manipulation a short-term reduction in temperature occurred in the furnace.

$$
q_{v}=\frac{6,62 \times 293}{T}
$$

Where qv is the speed of air-flow and $\mathrm{T}$ is absolute temperature in Kelvin [6].
Decomposition course of the fireproof coating Dexaflamm-R under isothermal conditions, expressed inpercentage of weight depending on time, for all observed temperatures are shown at Fig.3. Quantitative expression for each decomposition temperature with distribution to intermediate stages, the corresponding time interval and weight loss with an initial weight of samples are summarized at Tab. 2.

Decomposition at $600{ }^{\circ} \mathrm{C}$ was conducted in two intermediate stage of decomposition. During the first stage of decomposition weight loss was $15,1 \%$. During the second stage the weight loss was $35,11 \%$. The maximum mass loss rate 0,0099 g.s $^{-1}$ was achieved in $195 \mathrm{~s}$. Resistant residue after 1930 seconds of thermal stress was $49,76 \%$.

As at $600{ }^{\circ} \mathrm{C}$, the sample behaved even at $500{ }^{\circ} \mathrm{C}$. The first stage of decomposition was associated with $18,3 \%$ weight loss. The second stage was associated with $31.91 \%$ weight loss. During the second stage has been reached the maximum mass loss rate of $0,007 \mathrm{~g} . \mathrm{s}^{-1}$ at $385 \mathrm{~s}$. Resistant residue has value of $49,75 \%$ after 2175 seconds, it is the same value as at $600^{\circ} \mathrm{C}$.

At $400{ }^{\circ} \mathrm{C}$ decomposition conducted in three intermediate stage. The first was associated with weight loss $20,2 \%$. During the second intermediate stage of decomposition associated with weight loss $23,3 \%$, was reached the maximum mass loss rate of $0,0052 \mathrm{~g} . \mathrm{s}^{-1}$ at $560 \mathrm{~s}$. The third stage was carried out with slow weight loss of $6,81 \%$ in the range of 2300 seconds. At the end of the third stage of decomposition, resistant residue value reached $49,73 \%$, it is the same values as at $500{ }^{\circ} \mathrm{C}$ and $600{ }^{\circ} \mathrm{C}$.

Decomposition at $300^{\circ} \mathrm{C}$ was conducted again in two intermediate stage. During the first stage of decomposition weight loss was $21,2 \%$. The second stage of decomposition was associated with $19,8 \%$ weight loss. The largest weight loss occurred at the very beginning of the second stage, when was reached the maximum mass loss rate of 0,0034 g.s ${ }^{-1}$ at $975 \mathrm{~s}$. The other about 3000 seconds were associated with only a slight decrease in weight. Resistant residue was $59 \%$.

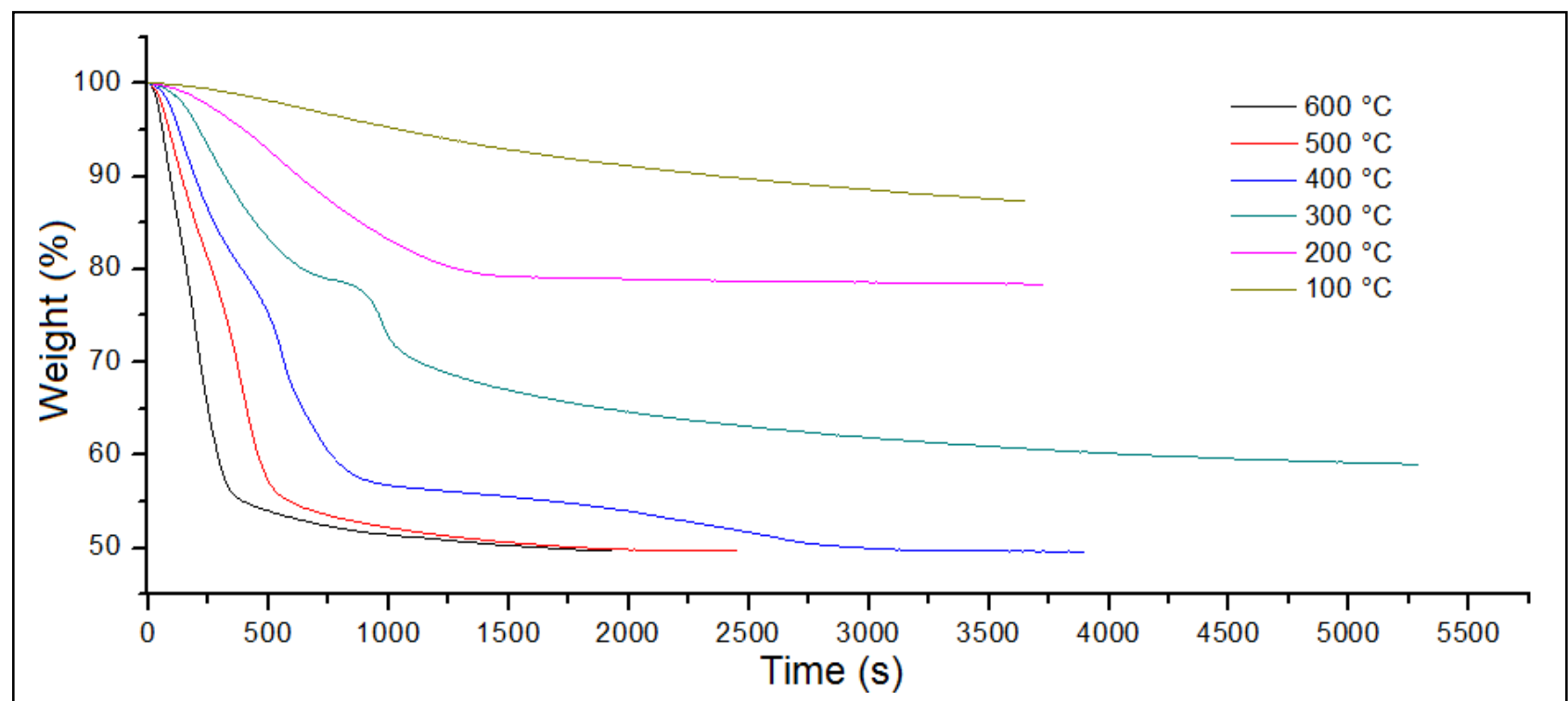

Fig. 3.Time dependance of weight for dexaflamm $\mathrm{R}$ samples under

various isothermic conditions 


\begin{tabular}{|c|c|c|c|c|c|c|}
\hline $\begin{array}{c}\text { Experimental } \\
\text { conditions } \\
\text { Sampe weight }[\mathrm{g}]\end{array}$ & $\begin{array}{c}\text { Decomposition } \\
\text { stages }\end{array}$ & $\begin{array}{c}\text { Temperature } \\
\text { range } \\
{\left[{ }^{\circ} \mathrm{C}\right]}\end{array}$ & $\begin{array}{c}\text { Mass loss } \\
{[\%]}\end{array}$ & $\begin{array}{c}\text { Temperature } \\
\text { at maximal } \\
\text { mass loss rate } \\
{\left[{ }^{\circ} \mathrm{C}\right]}\end{array}$ & $\begin{array}{l}\text { Maximal } \\
\text { mass loss } \\
\text { rate }\left[g_{. s}^{-1} \text { ] }\right.\end{array}$ & $\begin{array}{c}\text { Resistant residue } \\
\text { [\%] }\end{array}$ \\
\hline \multirow{2}{*}{$\begin{array}{l}600^{\circ} \mathrm{C} \\
5,520 \mathrm{~g} \\
\end{array}$} & First stage & $0-125$ & 15,13 & 70 & 0,0086 & 84,87 \\
\hline & Second stage & $125-1930$ & 35,11 & 195 & 0,0099 & 49,76 \\
\hline \multirow{2}{*}{$\begin{array}{l}500^{\circ} \mathrm{C} \\
5,566 \mathrm{~g}\end{array}$} & First stage & $0-240$ & 18,34 & 100 & 0,0056 & 81,66 \\
\hline & Second stage & $240-2175$ & 31,91 & 385 & 0,0070 & 49,75 \\
\hline \multirow{3}{*}{$\begin{array}{l}400{ }^{\circ} \mathrm{C} \\
5,405 \mathrm{~g}\end{array}$} & First stage & $0-395$ & 20,2 & 130 & 0,0042 & 79,8 \\
\hline & Second stage & $395-1065$ & 23,26 & 560 & 0,0052 & 56,54 \\
\hline & Third stage & $1065-3350$ & 6,81 & 2205 & 0,0002 & 49,73 \\
\hline \multirow{2}{*}{$\begin{array}{l}300^{\circ} \mathrm{C} \\
5,435 \mathrm{~g}\end{array}$} & First stage & $0-775$ & 21,2 & 225 & 0,0027 & 78,8 \\
\hline & Second stage & $775-5285$ & 19,8 & 975 & 0,0034 & 59 \\
\hline $\begin{array}{l}200^{\circ} \mathrm{C} \\
5,400 \mathrm{~g} \\
\end{array}$ & First stage & $0-3730$ & 21,63 & 555 & 0,0013 & 78,37 \\
\hline $\begin{array}{l}100^{\circ} \mathrm{C} \\
5,505 \mathrm{~g}\end{array}$ & First stage & $0-3645$ & 12,66 & 740 & 0,0004 & 87,34 \\
\hline
\end{tabular}

Tab. 2. Results of the thermal decomposition of Dexaflamm R during isothermal temperatures

At temperature of $200{ }^{\circ} \mathrm{C}$ decomposition took place only in one stage with $21,63 \%$ weight loss. The highest mass loss rate $0,0013 \mathrm{~g} . \mathrm{s}^{-1}$ was reached in 555 second. After 3730 seconds, there were no further loss of weight and resistant residue was $78,73 \%$.

Also at temperature of $100{ }^{\circ} \mathrm{C}$ decomposition took place only in one stage. During this stage the decomposition took place only very slowly. At this temperature, there was probably only the evaporation of water from the sample. The residue after 3730 seconds was $87,34 \%$.

Resistant residue after the thermal decomposition at temperatures of $600{ }^{\circ} \mathrm{C}, 500{ }^{\circ} \mathrm{C}, 400{ }^{\circ} \mathrm{C}$ had almost the same value of $49,7 \%$. At $300^{\circ} \mathrm{C}$ was resistant residue $59 \%$ which means that the sample did not decompose completely and contained a substance that was able to decompose only at higher temperatures.

Photography of the sample after thermal decomposition is showed at Fig. 4.

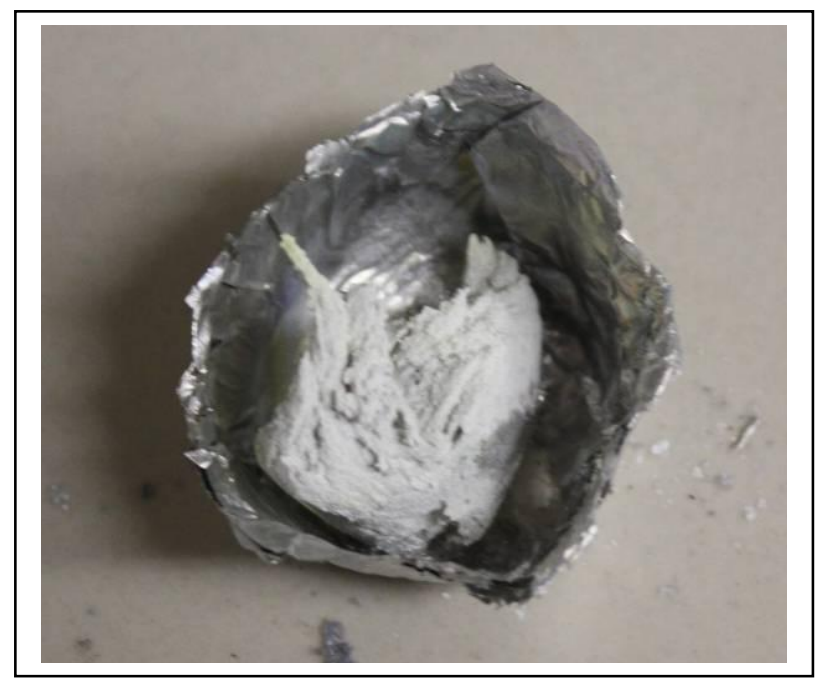

Fig. 4.Visualization of the samples after thermal degradation

\section{CONCLUSION}

On the basis of the performed measurements and by visual observation can be stated that the fireproof coat with increasing temperature will decompose to the inorganic alumino-silicate fiber residue which is about 50 $\%$.In terms of fire the fireproof coating will create on a surface of cable a hard layer with lower thermal conductivity and higher thermal capacity, which will ensure increased protection of cables, compared to unprotected cable. By creating a non-combustible layer the plastic insulation of cables is separated from the fire, the cable itself will not contribute to the development of a fire.

\section{REFERENCES}

[1] Netopilova, M. 2004. Materials: construction materials, Ostrava : Sdružení požárního a bezpečnostního inženýrství v Ostravě, 2004. 125 s. ISBN 80-86634-27-2

[2] Vašátko, E. 2011. 06100 Protection of cable distribution: DEXAFLAMM R. [s.1.] : [s.a.], 2011. [cit. 2012-01-21]. Dostupné na internete:

<http://www.seidl.cz/cz/katalog/ostatni/06100-ochranakabelovych-rozvodu-dexaflamm-r-119.html>

[3] Safety data sheet of Desaflamm-R: http://www.torasro.cz/index.php?mod=produkty\&typ=2

[4] STN EN 13 501-1+A1:2010 : Fire classification of construction products and building elements. Part 1: Classification using data from reaction to fire tests 978-1-891389-21-4, CA: University Science, 2002

[5] Chrebet, T.: Influence of eternal condition on ignition of wood and materials on the base of wood, Dissertation Thesis, Slovak university of technology in Bratislava, MTF STU, 2010, 138 p

[6] ISO 871:2006 Plastics - Determination of ignition temperature using a hot-air furnace 